\title{
Effect of Organic Manures and Inorganic Fertilizers on Soybean Yield, Nutrient Content and Uptake
}

\author{
Rani Bathula $^{1 *}$, Rajeshwar Malawath ${ }^{1}$, T. Anjaiah ${ }^{1}$ and M. Govardhan ${ }^{2}$ \\ ${ }^{1}$ Department of Soil Science and Agriculture Chemistry, ${ }^{2}$ AICRP on Integrated Farming \\ System, P.J.T.S.A.U, Hyderabad, Telangana, India \\ *Corresponding author
}

Keywords

Soybean, FYM, Leaf fall, Nutrient uptake

Article Info

Accepted:

18 April 2019

Available Online:

10 May 2019
A B S T R A C T

A field experiment was conducted at research farm of Agricultural Research Institute (ARI), Rajendranagar, Hyderabad, Telangana. The experiment was laid out in factorial combination of with and without leaf fall and increasing levels of $\mathrm{N}$ along with FYM application in randomized complete block design, each plot measuring $6.1 \mathrm{~m} \mathrm{x} 4.2 \mathrm{~m}$ and three replications. ADB-22 (Bhasar) a high yielding variety of soybean was used as the test crop in this experiment. The soil was black clay in texture and moderately alkaline $(\mathrm{pH}$ $8.4)$ in reaction, non-saline in nature $\left(\mathrm{EC} 0.16 \mathrm{dS} \mathrm{m} \mathrm{m}^{-1}\right)$ and high in organic carbon content (0.67\%). The experiment consisted treatments were viz.,75\% RDF, 100\% RDF, 75\% RDF +FYM@5 t ha ${ }^{-1}, 100 \%$ RDF + FYM @ $5 \mathrm{t} \mathrm{ha}^{-1}$ and in addition absolute control was maintained. The highest grain yield $2318 \mathrm{~kg} \mathrm{ha}^{-1}$ was recorded with application of $100 \%$ $\mathrm{RDF}+\mathrm{FYM} @ 5 \mathrm{t} \mathrm{ha}^{-1}$ along with leaf fall incorporation. The $\mathrm{N}$ content in soybean seeds ranged from $1.74 \%$ in control to $2.70 \%$ in $100 \%$ RDF + FYM @ $5 \mathrm{t} \mathrm{ha}^{-1}$. The highest total $\mathrm{N}$ uptake was $113.44 \mathrm{~kg} \mathrm{ha}^{-1}$ in $100 \% \mathrm{RDF}+\mathrm{FYM} @ 5 \mathrm{t} \mathrm{ha}^{-1}$ with leaf fall incorporation.

\section{Introduction}

Soybean is one of the most important oil seed crop in the world. Oil and protein rich soybean has now been recognized all over the world as a potential supplementary source of edible oil and nutrition (Kaul and Das, 1986). The oil of soybean contains $85 \%$ unsaturated fatty acid and is cholesterol free. Soybean seeds contain $43.2 \%$ protein, $19.5 \%$ fat, $20.9 \%$ carbohydrate and a good amount of other nutrients like calcium, phosphorus, iron and vitamins (Guptha et al., 2003). In Indian soils, the $\mathrm{N}$ is commonly the most limiting plant nutrient and has very low content because of low organic matter accumulation due to tropical climate. Nutrient availability especially $\mathrm{N}$ in the soil depend on organic matter decomposition and mineralization processes. Soil mineralization is influenced by biomass inputs, microbial activities, and different abiotic factors such as micro climatic variations and agricultural practices. Recycling of organic matter from the plants residues is an important source of nitrogen. It is maintained through mineralization and immobilization processes in agro ecosystems. Keeping this in view, a field study was conducted to know the effect 
of leaf fall incorporation with different levels of nitrogen on yield and nutrient uptake on soybean.

\section{Materials and Methods}

The present study was conducted during kharif 2016 at Agricultural Research Institute (ARI) Farm, Hyderabad, Telangana. Soil samples were analyzed for $\mathrm{pH}, \mathrm{EC}$, organic carbon, N, $\mathrm{P}$ and $\mathrm{K}$ by standard procedures (Jackson 1967). The soil was clay in texture and slightly alkaline ( $\mathrm{pH}$ 8.4) in reaction, nonsaline in nature (EC $0.16 \mathrm{dS} \mathrm{m} \mathrm{m}^{-1}$ ) and high in organic carbon content $(0.67 \%)$ The available Nitrogen $278 \mathrm{Kg} \mathrm{ha}^{-1}$, Phosphorus $23 \mathrm{Kg} \mathrm{ha}^{-1}$, Potassium $319 \mathrm{Kg} \mathrm{ha}^{-1}$. The experiment was laid out in factorial combination of with and without leaf fall incorporation along with inorganic fertilizers and FYM following randomized complet block design, each plot measuring $6.1 \mathrm{~m} \quad \mathrm{x} \quad 4.1 \mathrm{~m}$ and three replications. The experiment consisted Treatments were viz.0, 75\% RDF, 100 RDF, $75 \%$ RDF + FYM and $100 \%$ RDF + FYM and with and without incorporation of leaf fall. In selected treatment plots FYM was applied one week before sowing mixed thoroughly with soil. The fertilizers treatments urea $(46 \%-\mathrm{N})$, $\mathrm{SSP}\left(16 \%-\mathrm{P}_{2} \mathrm{O}_{5}\right)$, MOP $\left(60 \%-\mathrm{K}_{2} \mathrm{O}\right)$ were used as source of NPK and recommended dose of fertilizers was 80-60-40 $\mathrm{kgha}^{-1} \mathrm{NPK}$. The hole of the SSP and half of the urea fertilizer were applied as basal dose, remaining urea fertilizer were applied after 30 days of sowing. Bhasar (ADB-22) a high yielding variety of soybean was used as the test crop in this experiment. The experimental field was ploughed with tractor-drawn plough twice and finally with cultivator followed by rotovator to get fine tilth. Later the stubbles were removed and the field was uniformly leveled and layout was implemented for kharif soybean. The crop was harvested each plot wise and the yields were expressed in $\mathrm{kg} \mathrm{ha}^{-1}$. Plant samples were collected from every individual plot for chemical analysis. Grain and haulm yields were recorded separately for each plot. Plotwise grain and haulm samples collected were analysed for nutrient content following standard procedures (Piper, C.S. 1966). The uptakes of nutrients were calculated using the nutrient content and yield of grain and haulm.

Nutrient uptake $\left(\mathrm{kg} \mathrm{ha}^{-1}\right)=$

Nutrient content $(\%) \times$ yield $\left(\mathrm{kg} \mathrm{ha}^{-1}\right)$

\section{0}

\section{Results and Discussion}

\section{Grain and haulm yield}

The data pertaining to effect of fertilizers and manures with and without incorporation of leaf fall on grain and haulm yield of soybean has been presented in Table 1. The highest grain yield was obtained with the application of $100 \%$ RDF + FYM @ $5 \mathrm{t} \mathrm{ha}^{-1}\left(\mathrm{~T}_{5}\right)(2194 \mathrm{~kg}$ $\left.\mathrm{ha}^{-1}\right)$ and it was on par with the application of $75 \%$ RDF + FYM @ $5 \mathrm{t} \mathrm{ha}^{-1}\left(\mathrm{~T}_{4}\right)(2094 \mathrm{~kg}$ $\left.\mathrm{ha}^{-1}\right)$ and $\mathrm{T}_{4}$ treatment is on par with $\mathrm{T}_{3}(100 \%$ RDF) (1899 kg ha ${ }^{-1}$ ).

$\mathrm{T}_{4}$ and $\mathrm{T}_{3}$ were significantly superior to $\mathrm{T}_{2}$ Fertilizer treatment $\mathrm{T}_{1}$ produced lowest (1098 $\mathrm{kg} \mathrm{ha}^{-1}$ ) grain yield compared to remaining all other treatments. $\mathrm{T}_{5}$ and $\mathrm{T}_{4}$ recorded higher yield as compared to all other treatments. The beneficial effect of FYM was exhibited only when it was applied in conjunction with chemical fertilizers which could be due to synergistic role of FYM in increased the nutrient availability and sustaining the yield over a period of time as compared on their individual application. However the interaction effect of fertilizer treatments and leaf fall has shown inconsistence which resulted in non significant.

Among the treatments the highest haulm yield was obtained with the application of $100 \%$ 
$\mathrm{RDF}+\mathrm{FYM} @ 5 \mathrm{t} \mathrm{ha}^{-1}\left(\mathrm{~T}_{5}\right)\left(2852 \mathrm{~kg} \mathrm{ha}^{-1}\right)$ and it was on par with the application of $75 \%$ RDF + FYM @ $5 \mathrm{t} \mathrm{ha}^{-1}\left(\mathrm{~T}_{4}\right)\left(2690 \mathrm{~kg} \mathrm{ha}^{-1}\right)$ and $\mathrm{T}_{4}$ treatment is on par with $\mathrm{T}_{3}(100 \% \mathrm{RDF})$ $\left(2517 \mathrm{~kg} \mathrm{ha}^{-1}\right) . \mathrm{T}_{5}$ and $\mathrm{T}_{4}$ recorded higher haulm yield than other treatments. The interaction effect of fertilizer treatments and leaf fall has shown inconsistence which resulted in non significant

From the above results it could be observed that increased yield might be due to rapid mineralization of $\mathrm{N}$ from organics which might have met the $\mathrm{N}$ requirement of the crop at critical stages. Organics act as nutrient reservoir and upon decomposition produced organic acid, thereby absorbed ions were release slowly during entire growth period leading to higher yield. Similar findings are reported by Mahesh Babu et al., (2008). Vibielie Mere (2012) reported that application of $125 \% \mathrm{RDF}+\mathrm{FYM} @ 5 \mathrm{t} \mathrm{ha}^{-1}$ was recorded higher grain yield due to higher assimilation of nutrients.

\section{Nutrient content (\%) and nutrient uptake (kg ha ${ }^{-1}$ ) at harvest}

It is essential to determine amount of nutrients removed by crop to improve the production effiency as well as to know the soil fertility status. Amount of uptake of nutrients by crop increased with increased levels of fertilizer application.

\section{Nitrogen content and uptake}

It is evident from the data (Table 2) the nitrogen content of Soybean significantly influenced by various treatments. The incorporation of leaf falls as a non significant effect on $\mathrm{N}$ content. The maximum $\mathrm{N}$ content in grain $(2.70 \%)$, haulm $(1.64 \%)$ was recorded with treatment receiving $100 \% \mathrm{RDF}+\mathrm{FYM}$ @ $5 \mathrm{t} \mathrm{ha}^{-1}\left(\mathrm{~T}_{5}\right)$ and was on par with $75 \% \mathrm{RDF}$ +FYM@5 t ha ${ }^{-1}\left(\mathrm{~T}_{4}\right)$. Whereas lowest nitrogen content recorded in $\mathrm{T}_{1}$. The interaction effect of fertilizer treatments and leaf fall did not influence the $\mathrm{N}$ content in grain and haulm at harvest. The increased in $\mathrm{N}$ content might be due to enhanced symbiosis fixation (Singh et al., 2016). Nitrogen content was found to increase in direct proportion with the application of increased levels of nitrogen. Similar results are given by Vibielie Mere (2012), Meshram (2013).

Higher total uptake of nitrogen was recorded with application of 100\% RDF + FYM @ $5 \mathrm{t}$ $\mathrm{ha}^{-1}\left(\mathrm{~T}_{5}\right)\left(106.12 \mathrm{~kg} \mathrm{ha}^{-1}\right)$ and was on par with $75 \%$ RDF + FYM @ 5 t ha ${ }^{-1}\left(\mathrm{~T}_{4}\right)(97.34 \mathrm{~kg}$ $\mathrm{ha}^{-1}$ ) and $\mathrm{T}_{4}$ on par with treatment receiving $100 \% \operatorname{RDF}\left(\mathrm{T}_{3}\right) \quad\left(86.01 \mathrm{~kg} \mathrm{ha}^{-1}\right)$. Lowest nitrogen uptake recorded in $\mathrm{T}_{1}\left(32.71 \mathrm{~kg} \mathrm{ha}^{-1}\right)$. The interaction effect of fertilizer treatments and leaf fall had shown non significant. The increase in the $\mathrm{N}$ uptake might be attributed to the increase in number of nodules and thereby increasing the fixation of $\mathrm{N}$ by the plant and also due to utilization of carbohydrates for protein synthesis (Vibielie Mere, 2012).

\section{Phosphorus content and uptake}

It is apparent from the data (Table 3) that the phosphorus content of Soybean significantly influenced by various treatments. Higher $P$ content in grain and haulm recorded with treatment involving $100 \% \mathrm{RDF}+5 \mathrm{t} \mathrm{ha}{ }^{-1} \mathrm{FYM}$ $\left(\mathrm{T}_{5}\right)(0.49 \%, 0.32 \%$, respectively) and was on par with $\mathrm{T}_{4} \quad\left(75 \%\right.$ RDF $+5 \mathrm{t}$ ha $^{-1}$ FYM $)$ $(0.48 \%, 0.31 \%$ in grain and haulm respectively) and $\mathrm{T}_{4}$ was on par with $100 \%$ $\operatorname{RDF}\left(\mathrm{T}_{3}\right)(0.46 \%$ and $0.29 \%$ in grain and haulm respectively).

However $T_{3}$ significantly superior to $T_{2}$. Whereas lowest $\mathrm{P}$ content recorded in grain and haulm in control. However the interaction effect of leaf fall and treatments was non significant with regard to the $\mathrm{P}$ content in grain and haulm. 
Table.1 Effect of treatments on grain yield $\left(\mathrm{kg} \mathrm{ha}^{-1}\right)$ and haulm yield $\left(\mathrm{kg} \mathrm{ha}^{-1}\right)$ at harvest of soybean during kharif season

\begin{tabular}{|c|c|c|c|c|c|c|}
\hline \multirow{2}{*}{ Treatments } & \multicolumn{3}{|c|}{ Grain yield $\left(\mathrm{kg} \mathrm{ha}^{-1}\right)$} & \multicolumn{3}{|c|}{ haulm yield $\left(\mathrm{kg} \mathrm{ha}^{-1}\right)$} \\
\hline & $\mathrm{F}_{0}$ & $\mathrm{~F}_{1}$ & Mean & $\mathrm{F}_{0}$ & $\mathrm{~F}_{1}$ & Mean \\
\hline $\mathbf{T}_{1}$ & 1092 & 1104 & 1098 & 1312 & 1321 & 1317 \\
\hline $\mathbf{T}_{2}$ & 1398 & 1515 & 1457 & 2069 & 2169 & 2119 \\
\hline $\mathbf{T}_{\mathbf{3}}$ & 1831 & 1966 & 1899 & 2330 & 2704 & 2517 \\
\hline $\mathbf{T}_{4}$ & 2033 & 2156 & 2095 & 2617 & 2763 & 2690 \\
\hline $\mathbf{T}_{5}$ & 2070 & 2318 & 2194 & 2759 & 2944 & 2852 \\
\hline \multirow[t]{2}{*}{ Mean } & 1685 & 1812 & & 2217 & 2380 & \\
\hline & $\mathrm{SE} \pm(\mathrm{m})$ & $\mathrm{CD}$ & & $\mathrm{SE} \pm(\mathrm{m})$ & $\mathrm{CD}$ & \\
\hline Leaf fall & 43.04 & NS & & 60.64 & NS & \\
\hline $\begin{array}{l}\text { Fertilizer } \\
\text { Treatments }\end{array}$ & 68.06 & 203.06 & & 95.87 & 286.06 & \\
\hline Interaction & 96.24 & NS & & 135.58 & NS & \\
\hline $\mathrm{CV} \%$ & 9.54 & & & 10.22 & & \\
\hline
\end{tabular}

$\mathrm{F}=\mathrm{F}_{0}=$ without leaf fall, $\mathrm{F}_{1}=$ with leaf fall. Treatments $(\mathrm{T})=\mathrm{T}_{1}=$ Control, $\mathrm{T}_{2}=75 \% \mathrm{RDF}, \mathrm{T}_{3}=100 \% \mathrm{RDF}, \mathrm{T}_{4}=75 \% \mathrm{RDF}+\mathrm{FYM} 5 \mathrm{t}$ ha ${ }^{-1}, \mathrm{~T}_{5}=100 \% \mathrm{RDF}+\mathrm{FYM} 5 \mathrm{t}$ ha $^{-1}$ 
Table. 2 Effect of treatments on $\mathrm{N}$ content $(\%)$ and $\mathrm{N}$ uptake $\left(\mathrm{kg} \mathrm{ha}^{-1}\right)$ at harvest of soybean during kharif season

\begin{tabular}{|c|c|c|c|c|c|c|c|c|c|c|c|c|c|c|c|}
\hline \multirow[t]{3}{*}{ Treatments } & \multicolumn{6}{|c|}{$\mathrm{N}$ content $(\%)$} & \multicolumn{9}{|c|}{ N uptake $\left(\mathrm{Kg} \mathrm{ha}^{-1}\right)$} \\
\hline & \multicolumn{3}{|c|}{ Grain } & \multicolumn{3}{|c|}{ Haulm } & \multicolumn{3}{|c|}{ Grain } & \multicolumn{3}{|c|}{ Haulm } & \multicolumn{3}{|c|}{ Total } \\
\hline & $\mathrm{F}_{0}$ & $\mathrm{~F}_{1}$ & Mean & $\mathrm{F}_{0}$ & $F_{1}$ & Mean & F0 & F1 & Mean & $\mathrm{F}_{0}$ & $\mathrm{~F}_{1}$ & Mean & $\mathrm{F}_{0}$ & $\mathrm{~F}_{1}$ & Mean \\
\hline $\mathbf{T}_{1}$ & 1.69 & 1.78 & 1.74 & 1.00 & 1.07 & 1.04 & 18.45 & 19.65 & 19.05 & 13.12 & 14.19 & 13.63 & 31.57 & 33.84 & 32.71 \\
\hline $\mathbf{T}_{2}$ & 2.23 & 2.29 & 2.26 & 1.41 & 1.42 & 1.42 & 31.18 & 34.69 & 32.93 & 29.17 & 30.80 & 29.99 & 60.35 & 65.49 & 62.92 \\
\hline $\mathbf{T}_{\mathbf{3}}$ & 2.43 & 2.55 & 2.49 & 1.50 & 1.57 & 1.54 & 44.49 & 50.13 & 47.31 & 34.95 & 42.45 & 38.70 & 79.44 & 92.58 & 86.01 \\
\hline $\mathbf{T}_{4}$ & 2.55 & 2.63 & 2.59 & 1.56 & 1.64 & 1.60 & 51.84 & 56.70 & 54.27 & 40.83 & 45.31 & 43.07 & 92.67 & 102.02 & 97.34 \\
\hline $\mathbf{T}_{5}$ & 2.64 & 2.76 & 2.70 & 1.60 & 1.68 & 1.64 & 54.65 & 63.98 & 59.31 & 44.14 & 49.46 & 46.80 & 98.79 & 113.44 & 106.12 \\
\hline Mean & 2.31 & 2.40 & & 1.42 & 1.48 & & 40.12 & 45.03 & & 32.44 & 36.43 & & 72.56 & 81.47 & \\
\hline & $\mathrm{SE} \pm(\mathrm{m})$ & $\mathrm{CD}$ & & $\mathrm{SE} \pm(\mathrm{m})$ & $\mathrm{CD}$ & & $\mathrm{SE} \pm(\mathrm{m})$ & $\mathrm{CD}$ & & $\mathrm{SE} \pm(\mathrm{m})$ & $\mathrm{CD}$ & & $\mathrm{SE} \pm(\mathrm{m})$ & $\mathrm{CD}$ & \\
\hline Leaf Fall & 0.03 & NS & & 0.02 & NS & & 1.64 & NS & & 1.32 & NS & & 2.93 & NS & \\
\hline $\begin{array}{c}\text { Fertilizer } \\
\text { Treatments }\end{array}$ & 0.05 & 0.16 & & 0.04 & 0.11 & & 2.58 & 7.71 & & 2.09 & 6.24 & & 4.63 & 13.83 & \\
\hline Interaction & 0.08 & NS & & 0.05 & NS & & 3.65 & NS & & 2.96 & NS & & 6.55 & NS & \\
\hline CV\% & 5.71 & & & 6.01 & & & 14.85 & & & 14.88 & & & 14.74 & & \\
\hline
\end{tabular}

$\mathrm{F}=\mathrm{F}_{0}=$ without leaf fall, $\mathrm{F}_{1}=$ with leaf fall. Treatments $(\mathrm{T})=\mathrm{T}_{1}=$ Control, $\mathrm{T}_{2}=75 \% \mathrm{RDF}, \mathrm{T}_{3}=100 \% \mathrm{RDF}, \mathrm{T}_{4}=75 \% \mathrm{RDF}+\mathrm{FYM} 5 \mathrm{t}$ ha ${ }^{-1}, \mathrm{~T}_{5}=100 \% \mathrm{RDF}+\mathrm{FYM} 5 \mathrm{t}$ $\mathrm{ha}^{-1}$. 
Table.3 Effect of treatments on $\mathrm{P}$ content $(\%)$ and $\mathrm{P}$ uptake $\left(\mathrm{kg} \mathrm{ha}^{-1}\right)$ at harvest of soybean during kharif season.

\begin{tabular}{|c|c|c|c|c|c|c|c|c|c|c|c|c|c|c|c|}
\hline \multirow[t]{3}{*}{ Treatments } & \multicolumn{6}{|c|}{$P$ content $(\%)$} & \multicolumn{9}{|c|}{ P uptake $\left(\mathrm{Kg} \mathrm{ha}^{-1}\right)$} \\
\hline & \multicolumn{3}{|l|}{ Grain } & \multicolumn{3}{|l|}{ Haulm } & \multicolumn{3}{|l|}{ Grain } & \multicolumn{3}{|l|}{ Haulm } & \multicolumn{3}{|l|}{ Total } \\
\hline & $\mathrm{F}_{0}$ & $\mathrm{~F}_{1}$ & Mean & $\mathrm{F}_{0}$ & $\mathrm{~F}_{1}$ & Mean & F0 & $\mathrm{F} 1$ & Mean & $\mathrm{F}_{0}$ & $\mathrm{~F}_{1}$ & Mean & F0 & $\mathrm{F} 1$ & Mean \\
\hline $\mathbf{T}_{1}$ & 0.33 & 0.34 & 0.33 & 0.16 & 0.17 & 0.16 & 3.60 & 3.75 & 3.68 & 2.10 & 2.25 & 2.17 & 5.70 & 6.00 & 5.85 \\
\hline $\mathbf{T}_{2}$ & 0.36 & 0.38 & 0.37 & 0.21 & 0.22 & 0.22 & 5.03 & 5.76 & 5.39 & 4.34 & 4.77 & 4.56 & 9.37 & 10.53 & 9.95 \\
\hline $\mathbf{T}_{\mathbf{3}}$ & 0.45 & 0.47 & 0.46 & 0.28 & 0.30 & 0.29 & 8.24 & 9.24 & 8.74 & 6.52 & 8.11 & 7.32 & 14.76 & 17.35 & 16.06 \\
\hline $\mathbf{T}_{4}$ & 0.47 & 0.48 & 0.48 & 0.30 & 0.31 & 0.31 & 9.56 & 10.35 & 9.95 & 7.85 & 8.57 & 8.21 & 17.41 & 18.92 & 18.16 \\
\hline $\mathbf{T}_{5}$ & 0.48 & 0.50 & 0.49 & 0.31 & 0.33 & 0.32 & 9.94 & 11.59 & 10.76 & 8.55 & 9.73 & 9.13 & 18.49 & 21.32 & 19.89 \\
\hline \multirow[t]{2}{*}{ Mean } & 0.42 & 0.43 & & 0.25 & 0.27 & & 7.27 & 8.14 & & 5.87 & 6.68 & & 13.15 & 14.82 & \\
\hline & $\mathrm{SE} \pm(\mathrm{m})$ & $\mathrm{CD}$ & & $\mathrm{SE} \pm(\mathrm{m})$ & $\mathrm{CD}$ & & $\mathrm{SE} \pm(\mathrm{m})$ & $\mathrm{CD}$ & & $\mathrm{SE} \pm(\mathrm{m})$ & $\mathrm{CD}$ & & $\mathrm{SE} \pm(\mathrm{m})$ & $\mathrm{CD}$ & \\
\hline Leaf fall & 0.01 & NS & & 0.00 & NS & & 0.30 & NS & & 0.27 & NS & & 0.56 & NS & \\
\hline $\begin{array}{c}\text { Fertilizer } \\
\text { Treatments }\end{array}$ & 0.01 & 0.03 & & 0.01 & 0.02 & & 0.47 & 1.40 & & 0.40 & 1.19 & & 0.88 & 2.62 & \\
\hline Interaction & 0.01 & NS & & 0.01 & NS & & 0.66 & NS & & 0.57 & NS & & 1.24 & NS & \\
\hline CV\% & 5.05 & & & 6.39 & & & 14.89 & & & 15.56 & & & 15.38 & & \\
\hline
\end{tabular}

$\mathrm{F}=\mathrm{F}_{0}=$ without leaf fall, $\mathrm{F}_{1}=$ with leaf fall treatments $(\mathrm{T})=\mathrm{T}_{1}=$ Control, $\mathrm{T}_{2}=75 \% \mathrm{RDF}, \mathrm{T}_{3}=100 \% \mathrm{RDF}, \mathrm{T}_{4}=75 \% \mathrm{RDF}+\mathrm{FYM} \mathrm{5t}$ ha ${ }^{-1}$, $\mathrm{T}_{5}=100 \% \mathrm{RDF}+\mathrm{FYM} 5 \mathrm{t} \mathrm{ha}^{-1}$. 
Table.4 Effect of treatments on $\mathrm{K}$ content (\%) and $\mathrm{K}$ uptake $\left(\mathrm{kg} \mathrm{ha}^{-1}\right)$ at harvest of soybean during kharif season

\begin{tabular}{|c|c|c|c|c|c|c|c|c|c|c|c|c|c|c|c|}
\hline \multirow[t]{3}{*}{ Treatments } & \multicolumn{6}{|c|}{ K content $(\%)$} & \multicolumn{6}{|c|}{ K uptake $\left(\mathrm{Kg} \mathrm{ha}^{-1}\right)$} & \multirow{2}{*}{\multicolumn{3}{|c|}{ Total }} \\
\hline & \multicolumn{3}{|c|}{ Grain } & \multicolumn{3}{|c|}{ Haulm } & \multicolumn{3}{|c|}{ Grain } & \multicolumn{3}{|c|}{ Haulm } & & & \\
\hline & $\mathrm{F}_{0}$ & $\mathrm{~F}_{1}$ & Mean & $\mathrm{F}_{0}$ & $F_{1}$ & Mean & F0 & F1 & Mean & $\mathrm{F}_{0}$ & $\mathrm{~F}_{1}$ & Mean & F0 & F1 & Mean \\
\hline $\mathbf{T}_{1}$ & 0.76 & 0.83 & 0.80 & 1.57 & 1.81 & 1.69 & 8.30 & 9.16 & 8.73 & 20.60 & 23.91 & 22.25 & 28.90 & 33.07 & 30.98 \\
\hline $\mathbf{T}_{2}$ & 0.89 & 1.05 & 0.97 & 1.98 & 2.07 & 2.03 & 12.44 & 15.91 & 14.17 & 40.97 & 44.90 & 42.93 & 53.41 & 60.81 & 57.11 \\
\hline $\mathbf{T}_{3}$ & 1.13 & 1.17 & 1.15 & 2.17 & 2.20 & 2.19 & 20.69 & 23.00 & 21.85 & 50.56 & 59.49 & 55.02 & 71.25 & 82.49 & 76.87 \\
\hline $\mathbf{T}_{4}$ & 1.20 & 1.22 & 1.21 & 2.25 & 2.32 & 2.28 & 24.40 & 26.30 & 25.35 & 58.88 & 64.10 & 61.49 & 83.28 & 90.40 & 86.84 \\
\hline $\mathbf{T}_{5}$ & 1.22 & 1.23 & 1.23 & 2.31 & 2.34 & 2.33 & 25.25 & 28.51 & 26.88 & 63.73 & 68.89 & 66.31 & 88.98 & 97.40 & 93.19 \\
\hline \multirow[t]{2}{*}{ Mean } & 1.04 & 1.09 & & 2.06 & 2.15 & & 18.22 & 20.58 & & 46.95 & 52.26 & & 65.16 & 72.83 & \\
\hline & $\mathrm{SE} \pm(\mathrm{m})$ & $\mathrm{CD}$ & & $\mathrm{SE} \pm(\mathrm{m})$ & $\mathrm{CD}$ & & $\mathrm{SE} \pm(\mathrm{m})$ & $\mathrm{CD}$ & & $\mathrm{SE} \pm(\mathrm{m})$ & $\mathrm{CD}$ & & $\mathrm{SE} \pm(\mathrm{m})$ & $\mathrm{CD}$ & \\
\hline Leaf fall & 0.02 & NS & & 0.03 & NS & & 0.75 & NS & & 1.81 & NS & & 2.57 & NS & \\
\hline $\begin{array}{l}\text { Fertilizer } \\
\text { Treatments }\end{array}$ & 0.03 & 0.08 & & 0.05 & 0.15 & & 1.18 & 3.53 & & 2.87 & 8.55 & & 4.07 & 12.13 & \\
\hline Interaction & 0.04 & NS & & 0.07 & NS & & 1.67 & NS & & 4.05 & NS & & 5.75 & NS & \\
\hline CV\% & 6.41 & & & 5.85 & & & 14.95 & & & 14.16 & & & 14.46 & & \\
\hline
\end{tabular}

$\mathrm{F}=\mathrm{F}_{0}=$ without leaf fall, $\mathrm{F}_{1}=$ with leaf fall. Treatmlents $(\mathrm{T})=\mathrm{T}_{1}=$ Control, $\mathrm{T}_{2}=75 \% \mathrm{RDF}, \mathrm{T}_{3}=100 \% \mathrm{RDF}, \mathrm{T}_{4}=75 \% \mathrm{RDF}+\mathrm{FYM} 5 \mathrm{tha}{ }^{-1}, \mathrm{~T}_{5}=100 \% \mathrm{RDF}+\mathrm{FYM}$ $\left.5 \mathrm{t} \mathrm{ha}^{-1}\right)$ 
The increase in available $\mathrm{P}$ might be due to the organic acids, which were released during microbial decomposition of organic matter which helped in the solubility of native phosphates which resulted in higher $\mathrm{P}$ content in grain and haulm. The results are similar to the findings of Morshad et al, (2009).Sharma and Misra (1997).

Maximum $\mathrm{P}$ uptake by plant recorded with application of $100 \%$ RDF +FYM @ $5 \mathrm{t} \mathrm{ha}^{-1}$ $\left(\mathrm{T}_{5}\right)\left(19.89 \mathrm{~kg} \mathrm{ha}^{-1}\right)$ and was on par with $\mathrm{T}_{4}$ $\left(75 \% \mathrm{RDF}+\mathrm{FYM} @ 5 \mathrm{ha}^{-1}\right)\left(18.16 \mathrm{~kg} \mathrm{ha}^{-1}\right)$ and $\mathrm{T}_{4}$ was on par with $100 \% \operatorname{RDF}\left(\mathrm{T}_{3}\right)$ whereas lowest $\mathrm{P}$ uptake by plant recorded in control. However the interaction effect of leaf fall and treatments was non significant.

\section{Potassium content and uptake}

The data presented in Table 4 revealed that the potassium content and uptake in grain, haulm and total uptake by plant was not significantly influenced by the incorporation of leaf fall.

Among the treatments, the treatment $T_{5}$ recorded higher $\mathrm{K}$ content in grain and haulm $\left(1.23 \%, 2.33 \%\right.$ respectively). $\mathrm{T}_{5}$ on par with $\mathrm{T}_{4}(1.21 \%, 2.28 \%$ in grain and haulm respectively) and $\mathrm{T}_{4}$ on par with $\mathrm{T}_{3}(1.15 \%$, $2.19 \%$ in grain and haulm respectively). Whereas treatment $\mathrm{T}_{5}$ and $\mathrm{T}_{4}$ recorded significantly higher $\mathrm{K}$ content as compared to the all other treatments in grain and haulm. Lower $\mathrm{K}$ content recorded in $\mathrm{T}_{1}(0.80 \%$ and $1.69 \%$ in grain and haulm respectively). The higher availability of $\mathrm{K}$ may be due to beneficial effect of organic manures on the reduction of potassium fixation thereby enhance the content of $\mathrm{K}$ in grain and haulm. The results are in conformity with Bulluck et et al., (2002). Maximum total K uptake was observed with the application of $\mathrm{T}_{5}(100 \%$ $\left.\mathrm{RDF}+\mathrm{FYM} @ 5 \mathrm{t} \mathrm{ha}^{-1}\right)\left(93.19 \mathrm{~kg} \mathrm{ha}^{-1}\right)$ and was on par with $\mathrm{T}_{4}\left(86.84 \mathrm{~kg} \mathrm{ha}^{-1}\right)$. $\mathrm{T}_{4}$ on par with $\mathrm{T}_{3}$ ().Lower total $\mathrm{K}$ uptake by plant recorded in $\mathrm{T}_{1}\left(30.98 \mathrm{~kg} \mathrm{ha}^{-1}\right)$. Interaction effect of treatments and leaf fall has shown inconsistence which resulted in non significant.

Application of manure and fertilizers increased available $\mathrm{N}, \mathrm{P}_{2} \mathrm{O}_{5}$, and $\mathrm{K}_{2} \mathrm{O}$ in Soybean thereby uptake of NPK increased significantly. Similar results also reported by Patel and Chandravanshi (1996), Reddy et al, 2003. Najar et al., (2011) also reported increased uptake of nutrients with their increased application. Sharma and Misra (1997) also observed that the highest uptake of NPK by Soybean produced with the application of $20 \mathrm{~kg} \mathrm{~N}^{-1}$ along with FYM.

It is concluded, in this experiment among all the treatments T5 and T4 (100\% RDF +FYM @ 5t ha ${ }^{-1}, 75 \%$ RDF +FYM @ 5tha ${ }^{-1}$ ) shows higher grain, haulm yields and also nutrient content and uptake, it indicates that integrated nutrient management is best over the application of chemical fertilizers alone.

\section{References}

Bulluck, L.R., Brosius, M., Evanylo, G.K and Ristaino, J.B. 2002. Organic and synthetic fertility amendment influence soil microbial, physical and chemical properties on organic and conventional farms. Applied Soil Ecology 19: 147-160.

Gupta, V., Sharma, G.L., Sonakiya, V.K and Tiwari, G. 2003. Impact of different levels of FYM and sulphur on morphological indices and productivity of Soybean genotypes. JNKVV Research Journal, 37 (2):7678.

Jackson, M.L. 1967. Soil Chemical Analysis. Prentis Hall of India Pvt. Ltd., New Delhi. 111-203.

Kumar, B., Gupta, R.K and Bhandari, A.L. 2008. Soil fertility changes after long 
term application of organic manures and crop residues under rice-wheat system. Journal of Indian Society of Soil Science. 56(10): 80-85.

Mahesh Babu, H.M., Ravi Hunje, Biradar Patil, N.K and Babalad, H.B. 2008.Effect of organic manures on plant growth, seed yield and quality of Soybean. Karnataka Journal of Agricultural science. 21(2): 219-221

Meshram Nisha, 2013. Effect of Integrated Nutrient Management on growth and yield of Soybean (Glycine max (L.) Merrill). M.Sc. (Agriculture) Thesis. Jawaharlal Nehru Krishi Vishwa Vidyalaya, Jabalpur.

Morshed, R.M., Rahman, M.M and Rahman M.A. 2008.Effect of nitrogen on seed yield, protein content and nutrient uptake of Soybean (Glycine max L.) Journal of Agriculture and Rural development. 6(1): 13-17.

Najar, G.R., Singh, S.R., Akhtar, F.H and Hakeem, S.A. 2011. Influence of sulphur level on yield, uptake and quality of Soybean (Glycine max) under temperate conditions of Kashmir. Indian Journal of Agricultural Science, 81(4): 340-343.

Patel, S.R. and Chandravanshi, B.R. 1996. Nitrogen and phosphorus nutrition of Soybean (Glycine max) grown in Vertisols. Indian Journal of
Agronomy. 41(4): 601- 603.

Piper, C.S. 1966. Soil and Plant Analysis. Hans Publishers, Bombay, pp: 137 153.

Reddy, S.K., Muneshwar Singh, Awadesh Kumar Tripathi, Mahavir Singh and Manbendra Nath Saha. 2003. Changes in amount of organic and inorganic fractions of nitrogen in an Eutrochrept soil after long term cropping with different fertilizers and organic manure inputs. Journal of Plant Nutrition and Soil Science. 166: 232238.

Sharma, R.A. and Mishra, O.R. 1997. Crop residues, FYM and fertilizer use in relation to growth, yield and nutrient uptake of Soybean. Crop Research.13(1):51-57.

Singh, G., Pushkar Choudhary, S., Devendar, Rajveer Singh Rawat. And Dr. Bhanwar Lal Jat. 2016. Effect of organic and inorganic sources of nitrogen on growth and yield of Soybean under arid zone of Rajasthan. International Journal of Pharmaceutical Research and BioScience. 5(5): 131-153.

Vibielie Mere, 2012. Effect of organic, inorganic fertilizers on yield of Soybean. Ph.D. thesis submitted to Nagaland University, Medziphema.

\section{How to cite this article:}

Rani Bathula, Rajeshwar Malawath, T. Anjaiah and Govardhan, M. 2019. Effect of Organic Manures and Inorganic Fertilizers on Soybean Yield, Nutrient Content and Uptake. Int.J.Curr.Microbiol.App.Sci. 8(05): 2283-2291. doi: https://doi.org/10.20546/ijcmas.2019.805.269 